\title{
CR1 wt Allele
}

National Cancer Institute

\section{Source}

National Cancer Institute. CR1 wt Allele. NCI Thesaurus. Code C84438.

Human CR1 wild-type allele is located in the vicinity of $1 \mathrm{q} 32$ and is approximately $146 \mathrm{~kb}$ in length. This allele, which encodes complement receptor type 1 protein, plays a role in complement-mediated immunity. Genetic polymorphisms are associated with the extent of malarial rosetting, and can confer protection ag ainst severe malaria. Genetic variation of the gene may contribute to Alzheimer's Disease. 